\title{
安全なスポーツ環境の構築に向けて
}

\author{
Safety of Sports Equipment
}

宇 治 橋貞 幸

\begin{abstract}
最近のスポーツ用具の性能向上には目を見張るものがあるが，そのおもな要因は材料の進 歩に負うところが大きい。また同時に，快適なスポーツ環境を確保するうえで欠かすこと のできない安全性向上もその恩恵を受けている。ここでは, スポーツにおけるハード・ウ エアの性能向上とともに安全性がいかにして追及されているかについて紹介する。
\end{abstract}

\section{1. スポーツ用具における素材の変遷}

スポーツに扔けるハード・ウエアの中であとくに用具で は，1970 年代以降急速にプラスチック化が進行してきた。 表 1 は, 用具における素材の変化とその結果として性能が いかに進化してきたかを示したあのである。ほとんどすべ ての例において木材に代表される天然素材から（あるあの については短い金属の時代を経て）FRP（瀻維強化プラス チック：Fiber Reinforced Plastics）さらには ACM (Ad. vanced Composite Materials) を含む高分子材料へと変遷 してきた経過を示している。これには，大量生産の時代を 迎え天然素材の安定的な供給が困難となってきたことが背 景としてあげられる。

身近で代表的な例は，図 1 に示すテニス・ラケットであ ろう。1970 年頃までは木製以外のラケットは存在してい なかったが，その後ジュラルミン製が現れ新鮮な印象を与 えた。しかし，金属の時代は長く続かず，1970 年代後半に はFRP 製ラケットが出現しまたたく間に他の素材を圧倒 するようになった。現在のラケットに使用されている FRP の緎維は CF (Carbon Fiber) で，表 2 に示すように 軽くて強いのが最大の特徵である。この特徴を巧みに活か すことにより, 各種スポーツ用具に要求される固有の性能 をより高い次元で満足させる用具が出現してきた。

テニス・ラケットでは, 軽量でありながらフレームの高 剛性化と打球面拡大を同時に達成しプレーに大きな影響

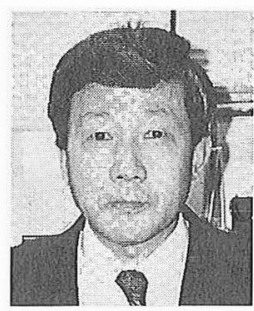

Sadayuki UJIHASHI

東京工業大学情報理工学研究科 (152-8552 東京都目黒区大岡山 2-12-1) ・教授, 工学 博士.

1971 年東京工業大学大学院理工学研究科修 士課程修了専門は安全工学, スポーッ工 学, バイオメカニクス, 衝撃工学 〈趣味〉ランニング, 登山
をあたらした。世界一流レベルのプレーヤーによるプレー においては, ラケットの性能向上が, プレーヤーの追従能 力を超えてしまうことによる負の効果む出ているが，一般 のテニス愛好者が享受している恩恵には, 計り知れないも のがある。ゴルフ・スキー・陸上競技などにおける用具に おいてあ同様であり, ハード・ウェアへのプラスチック導 入が記録向上の主たる原動力となってきている。

FRP を主としたプラスチックのスポーッ用具への適応 は, ガラス・ファイバー (GF) や CF の強度之軽さが際 立っていることと, 機能性材料としての FRP が高い設計 自由度をむっている点が大きな推進力となっている。たと えば, 強度に比べて弾性率の低い CF では，その特徴を引 き出すように設計すればフレキシブルでありながら高強度 な用具を実現させることができる。棒高跳のポールや釣竿 あるいはゴルフのクラブ : シャフト (図 2 参照) などはそ の良い例であろう。逆に高剛性が求められるテニス・ラ ケットや自転車のフレームなどでは，CF の軽さと成形性 を利用した高剛性断面形状の採用により, 要求性能を高度 に満たすことができる。またプラスチックは低い熱伝導特 性からくる温かみがあり，これもヒトが直接手にするス ポーッ用具の親和性を高めている。用具の高性能化に伴っ て確保されてきた高いパフォーマンスに対しては，より高 い安全性が求められてくる。

\section{2. スポーツ用具の安全基準}

プラスチック製品は，鉄やアルミニウムなどの金属材料 と異なりまだ歴史が浅く，とくにスポーツ用品において は，本格的な製品化が始まってからやっと 20 数年を経た にすぎない。また，プラスチックやFRP は破壊のクライ テリオンが十分に明らかになっておらず，とくに油や紫外 線による劣化・低温脆性など, 化学的および理学的環境下 
表 1 スポーツ用具における天然素材から高分子素材への变遷

\begin{tabular}{|c|c|c|c|}
\hline 種 目 & & 用具材料の変遷 & 効 \\
\hline ゴルフ & $\begin{array}{l}\text { (ポール) } \\
\text { (クラブシャフト) }\end{array}$ & $\begin{array}{l}\text { フェザリーーガッタパーチャ } \rightarrow \text { 糸巻き・ッーピース } \\
\text { 木材 } \rightarrow \text { スール } \rightarrow \mathrm{FRP} \rightarrow \mathrm{ACM}\end{array}$ & $\begin{array}{l}\text { 飛距離・強度向上 } \\
\text { 剛性・質量・慣性力配分変化 }\end{array}$ \\
\hline テニス & (ラケット) & 木材 $\rightarrow$ スチール・アルミニウム $\rightarrow \mathrm{FRP} \rightarrow \mathrm{ACM}$ & 打球面拡大，強度・剛性・空力特性向上 \\
\hline スキー & (板) & 木材 $\rightarrow$ アルミニウム $\rightarrow \mathrm{FRP} \rightarrow \mathrm{ACM}$ & 軽量化，高剛性化 \\
\hline 棒高跳 & (ポール) & 竹 $\rightarrow$ アルミニウム $\rightarrow \mathrm{FRP} \rightarrow \mathrm{ACM}$ & 軽量化, 記録向上 $(4.80 \rightarrow 6.14 \mathrm{~m})$ \\
\hline & (竿) & 竹 $\rightarrow \mathrm{CFRP}$ & 軽量化，強度・振動特性向上 \\
\hline 野球 & (バット) & 木材 $\rightarrow$ アルミニウム $\rightarrow \mathrm{CFRP}$ & 軽量化，強度向上 \\
\hline マラソン & (シューズソール) & 天然ゴム $\rightarrow$ 合成ゴム $\rightarrow$ 樹脂 (EVA) & 軽量化, 強度・衝撃吸収性向上 \\
\hline 剣道 & （竹刀） & 竹 $\rightarrow$ ACM & 軽量化，強度向上 \\
\hline 自動車レース & (ヘルメット) & スチール・アルミニウム $\rightarrow \mathrm{FRP}$ & 軽量化, 衝撃吸収性向上 \\
\hline 自転車 & (フレーム) & スチール $\rightarrow$ アルミニウム $\rightarrow \mathrm{FRP} \rightarrow \mathrm{ACM}$ & 軽量化 \\
\hline 陸上競技 & (サーフェス) & シンダーーアンツーカーーポリウレタン & 日程確保, 記録向上, 省メンテナンス \\
\hline
\end{tabular}

表 2 各種 FRP 繊維の性質

\begin{tabular}{|c|c|c|c|c|c|c|}
\hline 種 類 & タイプ & & 密 度 & $\begin{array}{c}\text { 引張強さ } \\
{[\mathrm{GPa}]}\end{array}$ & $\begin{array}{c}\text { 引張弾性率 } \\
\text { [GPa] }\end{array}$ & 引張破弾伸び \\
\hline 炭素繊維 & $\begin{array}{l}\text { 標準弾性率タイプ } \\
\text { 中間弾性率タイプ } \\
\text { 高弾性率タイプ } \\
\text { 汎用タイプ } \\
\text { 超高弾性率タイプ }\end{array}$ & $\begin{array}{l}\text { PAN 系 } \\
\text { PAN 系 } \\
\text { PAN 系 } \\
\text { ピッチ系 } \\
\text { ピッチ系 }\end{array}$ & $\begin{array}{l}1.76-1.82 \\
1.70-1.82 \\
1.76-1.97 \\
1.5-1.7 \\
2.10-2.19\end{array}$ & $\begin{array}{l}2.8-5.0 \\
4.3-6.9 \\
2.5-4.9 \\
0.5-1.0 \\
2.4-4.0\end{array}$ & $\begin{array}{r}2.5-235 \\
280-300 \\
345 / 640 \\
30-60 \\
700-900\end{array}$ & $\begin{array}{l}1.3-2.1 \\
1.3-2.4 \\
0.5-1.4 \\
0.9-2.0 \\
0.3-0.5\end{array}$ \\
\hline ガラス繊維 & $\begin{array}{l}\mathrm{E} \text { ガラス } \\
\mathrm{T} \text { ガラス }\end{array}$ & & $\begin{array}{l}2.54 \\
2.48\end{array}$ & $\begin{array}{l}3.5 \\
4.6\end{array}$ & $\begin{array}{l}73 \\
87\end{array}$ & $\begin{array}{l}4.8 \\
5.7\end{array}$ \\
\hline アラミド繊維 & $\begin{array}{l}\text { ケブラー } 49 \\
\text { ケブラー } 149\end{array}$ & & $\begin{array}{l}1.44 \\
1.45 \\
1.47\end{array}$ & $\begin{array}{l}3.62 \\
3.62 \\
3.44\end{array}$ & $\begin{array}{r}83 \\
124 \\
175\end{array}$ & $\begin{array}{l}4.4 \\
2.9 \\
1.9\end{array}$ \\
\hline
\end{tabular}

である。

[JIS 規格]

乗車用ヘルメット， つり針, 卓球台, ス キー用具，ダイビン グ用具

[SG 基準 $]$

金属製およびFRP 製バット，スキー 板/靴/締具, 口ラ・スケート，野球 用およびソフトボー

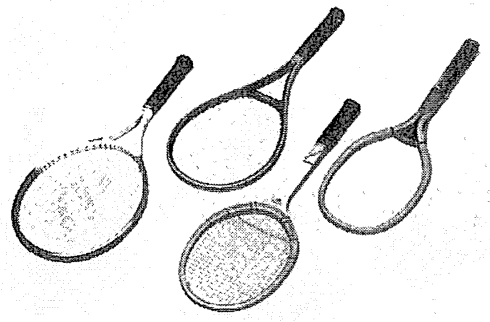

図 1 テニス・ラケットにおける素材の変遷

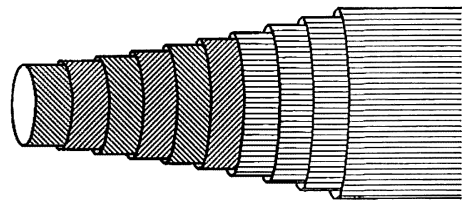

図 2 FRPによるクラブ・シャフトの作成例

での性質変化により強度が著しく低下する特性をすってお り, 用具の破壊に対する安全性とその経時変化に関して多 くの問題を含んでいる。

スポーツ用具の安全性を規定する基準には，日本工業規 格 (JIS) と製品安全協会による (SG) 基準があり，スポー ッ・レジャ一用品のうちで，とくに安全性の確保が重要な 用具について安全基準が制定されている。消費者はこれに 合格した製品を購入できるようになっており，安心してス ポーツを楽しむことのできる環境を提供するためのひとつ の制度となっている。現在，スポーッ・レジャ一用品のう ちで, 安全基準が制定されている主なものは以下のとおり
ル用ヘルメット, 水中マスク/フィン, 野球用およびソフ トボール捕手用ヘルメット，ハンドボール・ゴール，エ キスパンダ, サッカー・ゴール, カラビナ, 運動用マット, 登山用ヘルメット/ロープ/ヘルメット/ベルト, 跳箱/踏 切板, ハーケン, バレー・ボール器具; シュタイクアイ ゼン，ゴルフ・クラブ，アイスピッケルおよびアイス八 ンマ, スケート・ボード, バドミントン・ラケット, 乗車 用ヘルメット，とびなわ，自転車用ヘルメット，自転車

\section{3. ヘルメットによる頭部保護}

スポーツ障害を身体部位別にみると，上下肢が圧倒的に 多いが，症状の深刻さでは頭部があっとも重大である。ス キーやスノー・ボードなどウインタースポーッ，登山，自 転車, 野球やホッケーなどの球技, アメリカンフットボー ル，ローラ・スケートなど頭部が衝撃にさらされる可能性 の高いスポーツ種目はきわめて多い。しかし，競技規則の 適用を受けない一般のスポーッの場面では，ヘルメットの 着用率はきわめて低く，また頭部を衝撃から保護する性能 がきわめて不十分なヘルメットが多く販売されているのが 現状である。そこで，その保護用品としての重要性の認識 を高めるためにヘルメットの頭部保護のメカニズムを紹介 した(い1)22)

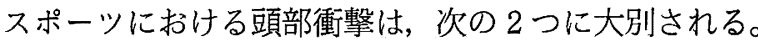




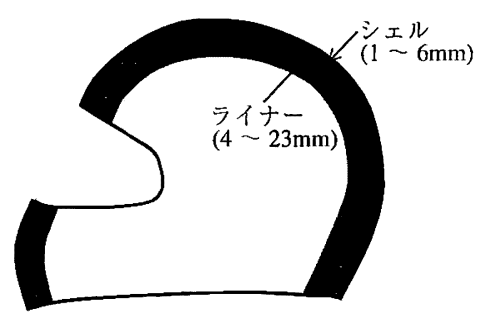

図 3 ヘルメットの断面概略図

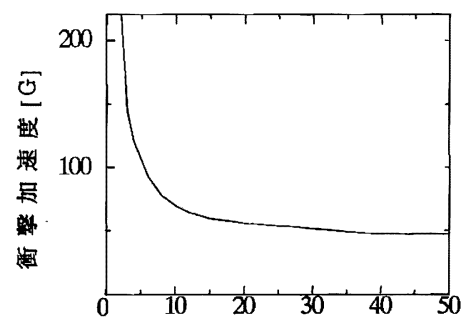

持続時間 [ms]

図 4 衝撃を受ける頭部の耐性曲線 $\mathrm{k}$

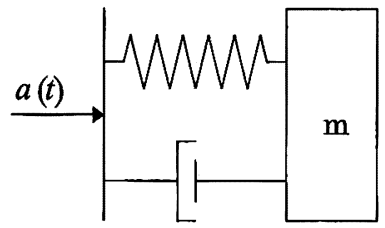

C

図 5 脳の力学モデル
（1）ボールのような比較的軽い物体(野球)による高速衝突

(2) 疾走中の固定物への衝突や転倒によるサーフェイスへ の低速衝突

前者では，衝撃のパルスは高く短い傾向があり，後者で は逆に低く長い傾向がある。したがって, 前者では図 3 に 示すようにおむにシェルによるエネルギー吸収が期待さ れ, 残存衝撃エネルギーが大きい状態でのシェルの破壊は 避けなければならない。後者はライナーによるエネルギー 吸収が重要になる。ライナーの圧縮限界である底付き現象 ライナーの含まれる空孔が潰れきってしまいエネルギー吸 収の限界に達した状態を避けなければならない。

頭部に加えられた衝撃が許容範囲内であるか否かの評価 手法には, 頭部に生ずる加速度応答を積分し, その数值の 大小によって評価する方法（積分型指標）と加速度応答を 脳の力学モデルへ入力し, その変位の大小によって評価す る方法 (力学モデル型指標) が提案されている。これらの 方法は, いずれも図 4 に示す衝撃を受ける頭部の耐性曲線 (WSTC: Wayne State Tolerance Curve) に基づいて求め られており，概略を示すと以下のとおりである。

[1] 積分型指標 (SI, HIC)

この指標は，計測された加速度波形が WSTC に当ては まるか否かを判定するための実験式である。これらの積分 式によって求められた数值は，1,000のときにWSTCを ほぼ近似していることがわかっている。したがって, SI あ るいは HIC の值が 1,000 以下であれば, 図 4 の安全域（曲 線の下側）と同等であると判定している。なお HIC は, SI に比べて積分の中に積分区間（式 (2) 右辺の $\left(t_{2}-t_{1}\right)$ を示 す）が入っているのが特徴である。

(a) SI (Severity Index)

$$
\begin{aligned}
\mathrm{SI}= & \int_{t_{a}}^{t_{b}} a(t)^{2.5} \mathrm{~d} t \\
\text { ここで, } & a(t): \text { 頭部の加速度応答 }[\mathrm{G}] \\
& t_{a}: \text { 加速度の立ち上がり時刻 }[\mathrm{s}] \\
& t_{b}: \text { 加速度の零への復帰時刻 }[\mathrm{s}]
\end{aligned}
$$

(b) HIC (Head Injury Criterion)

$$
\mathrm{HIC}=\left(t_{2}-t_{1}\right)\left\{\frac{\int_{t_{1}}^{t_{2}} a(t) \mathrm{d} t}{t_{2}-t_{1}}\right\}_{\max }^{2.5}
$$

ここで, $a(t)$ : 頭部の加速度応答 $[\mathrm{G}]$

$$
t_{1,2} \text { : 右辺が最大となる時刻 }\left(t_{1}<t_{2}\right)[\mathrm{s}]
$$

[2] 力学モデル型指標

この指標は, 図 5 のような脳の力学モデルへ計測された 加速度波形を入力した場合の変位量が, 臨界值を超えてい るか否かにより安全性を判定する方法である。

JTIの指標では, 力学モデルのパラメーターおよび WSTC に相当する安全域之危険域の境界である臨界值を 以下のように定義している。

JTI (Jienne Institute Index) 指標

モデルの諸元を $\omega=\sqrt{k / m}=635\left[\mathrm{rad} \mathrm{s}^{-1}\right]$,

$$
\beta=c / 2 \sqrt{m k}=1
$$

とした場合で, 臨界值は $2.35 \mathrm{~mm}$ とされている。

\section{4. ヘルメットの安全基準と試験法}

現在までにヘルメットの SG 基準として制定されてきた あのについて，その衝撃吸収性に関する規定内容を比較し てみると以下のようになる。なお，いずれも JIS で規定さ れている人頭模型 $(5 \mathrm{~kg})$ にヘルメットを被せて試験を行 うことが定められている。衝撃試験法には，図 6 のように 垂直に落下させる試験法とボールやストライカを衝突させ る試験法とがある。

（1）乗車用ヘルメット〈CPSA 0004/1974 年制定・ 1996 年改正〉

$\rightarrow$ 落下衝撃試験 $(1.7 \mathrm{~m})$ による加速度：300G 以下 および $150 \mathrm{G}$ 以上の加速度: $4 \mathrm{~m} \mathrm{~s}^{-1}$ 以下 [以上B種]

（2）野球用ヘルメット〈CPSA 0005/1974 年制定・ 1996 年改正〉

＼cjkstart硬式ボールの衝突 $\left(145 \mathrm{~g}, 30 \mathrm{~m} \mathrm{~s}^{-1}\right)$ による加速 度：250 G以下

（3）自転車用ヘルメット〈CPSA 0056/1983 年制定・ 1997 年改正〉

$\rightarrow$ 落下衝撃試験 $(1.0 \mathrm{~m})$ による加速度：300G 以下

（4）登山用ヘルメット〈CPSA0064/1984 年制定〉

ストライカの落下衝撃 $(5 \mathrm{~kg}, 2 \mathrm{~m})$ による衝撃 力: $10 \mathrm{kN}$ 以下

(5) 軟式野球用/ソフトボール用ヘルメット〈CPSA 


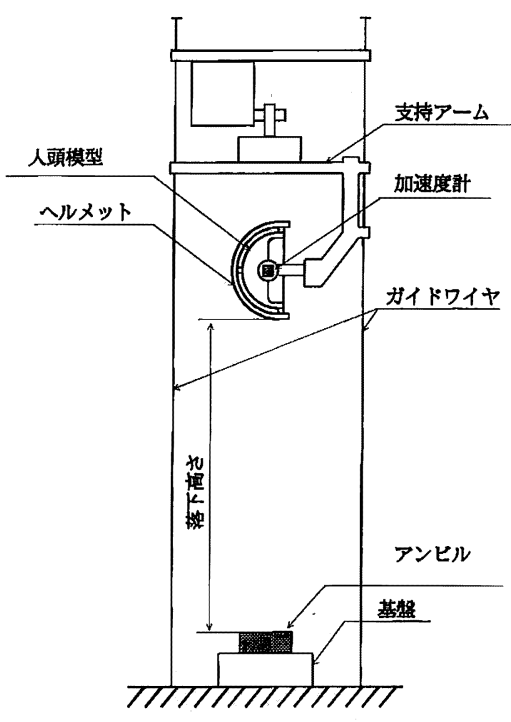

図 6

0072/1986 年制定〉

ーストライカの衝突による加速度：150 G以下 (600 g; 軟式: $7 . \mathrm{m} \mathrm{s}^{-1}$, ソフト 1 種: $10 \mathrm{~m} \mathrm{~s}^{-1}$ )

(6) 野球用/ソフトボール用捕手ヘルメット〈CPSA 0088/1990 年制定〉

ーストライカの衝乫 $\left(600 \mathrm{~g}, 10 \mathrm{~m} \mathrm{~s}^{-1}\right)$ による加速 度： $250 \mathrm{G}$ 以下

（7）野球投手用ヘッドギア〈CPSA0112/1998 年制定〉 $\rightarrow$ 硬式ボールの衝突 $\left(145 \mathrm{~g}, 40 \mathrm{~m} \mathrm{~s}^{-1}\right)$ による加速 度： $250 \mathrm{G}$ 以下, SI 指標 1,000 以下

(8) 雪上レジャー用ヘルメット〈CPSA0118/2000年制定〉 $\rightarrow$ 落下衝撃 $(1.5 \mathrm{~m})$ による加速度：250 G 以下

（9）雪上レジャー用ヘッドギア〈CPSA0119/2000年制定〉 $\rightarrow$ 落下衝撃 $(2.5 \mathrm{~m})$ による加速度：HIC 指標 1,000 以下 (緩衝面衝突)

これらを概観してみると, 最近制定された基準以外人頭 模型内は生ずる衝撃加速度応答の主に大きさの上限だけを 抑える方法で規定されている。しかし，GPSA0112 野球投 手用へッドギアでははじめて SI 指標が併用の形で採用さ れ, 雪上レジャー用へッドギアでははじめて HIC 指標だ けで安全基準が記述されている。

\section{5. ハード・ウエアと傷害防止の取り組み}

前述の用具の他にも怪我や傷害を防止する上で取組まな ければならない課題は多く, 活発な研究活動とその成果を 安全基準へと結びつける努力が望まれている。たとえば, 剣道における竹刀の FRP 化には竹製のあのとは異なった 危険性があり, 良質な竹の入手が困難となった現在, 安全 性の確保が普及を図るうえで重要な課題となっている。

陸上競技場のサーフェイスには，1968年のオリンピッ ク・メキシコ大会からポリウレタンが採用になり, その後 より記録の出る素材と構造の開発が盛んになった。しかし 一方で, 脚筋力への負担が増大し傷害に至る例が多く報告
されるようになった。サーフェイス の弾力性に対する評価法として，た とえば図 7 のような人間の足によ る着地衝撃を再現できるとした試験 装置が考案されている。競技者への 負担軽減を実現しかつ記録が出やす いサーフェイスとするにはどのよう な物理特性が必要なのかについて は, 研究課題となっている。また, 世界一流の競技者と一般のスポーツ 愛好者とでは最適性能は異なるの で, そのガイドラインとしての安全 基準が必要であろう。

スキーでは, 新品ではないが使用 履歴のほとんどないプラスチック・ ブーツが滑走中に突然破壊し，ス キーヤーが大怪我をした事例が続出 したことがあった。原因はプラスチックの劣化であり，直 ちに対策がとられた。この事故は，スポーッ用具へのプラ スチックの使用に歴史が浅かったことによる典型的な事例 であった。

また，新しいスポーツにおいても安全性に対する対策が 十分でない例が多く見られる。たとえば，スノ一・ボード ではおすに初心者が転倒し，手を雪面に着いたために手首 や腕に重度の怪我を負ったり，雪面に後頭部を打ち付け死 亡に至る例が続出している。これらの事故も手袋の工夫や 新しいヘッドギアの開発によりその傷害を防止しようとい う試みが続けられている。

\section{6. あとがき}

スポーツのハード , ウェアにプラスチックが広範囲に進 出し, その結果パフォーマンスが向上し, あるいはスポー ッがより多彩でより身近なあのになってきた。その中心と なっているのは, ガラス繊維や炭素繊維を用いた FRP で あり，高機能で魅力にあふれる用具の設計が可能になって きた。今後むさらに新素材の開発とスポーツ用具への適用 が試みられるであろう。

しかし FRP は環境問題を考えるとき, 問題のある材料 である。現在の FRP は，まったく性質の異なる素材の繊 維とプラスチックを組み合わせているため, 廃衰の際の分 別がほとんど不可能であり焼却あままならない。FRP の 今後の課題は廃棄あるいはリサイクルに適した基材の開発 あるいは成形法の研究であろう。この点での研究が大いに 進展することを大いに期待したい。

\section{文献}

1）製品安全協会 (製品と安全)，第 78 号，2000, pp. 13-20

2) 日本機械学会論文集 (A 編), 67158 (2001) 